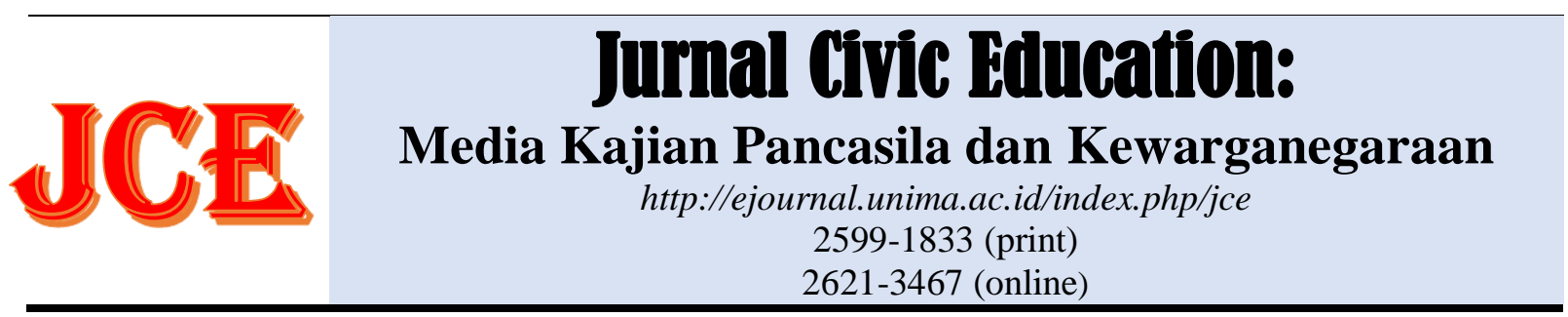

\title{
Hubungan Minat Belajar Dengan Prestasi Belajar Mahasiswa PPKn Semester 7 Pada Perkuliahan PKn
}

\author{
Jaya Sasube Sore, ${ }^{1 *}$, Natanael F. Kaunang ${ }^{b, 2}$, Theodorus Pangalila ${ }^{c, 3}$ \\ a Jurusan PPKn FIS Unima, Manado, Indonesia \\ *jayasore@gmail.com
}

\begin{tabular}{lll}
\hline Informasi artikel & ABSTRAK \\
\hline Sejarah artikel: & Penelitian ini bertujuan untuk mengetahui bagaimana hubungan minat \\
Diterima & $: 20-10-2019$ & belajar dengan prestasi belajar mahasiswa PPKn semester 7 pada \\
Revisi & $: 10-11-2019$ & perkuliahan PKN. Populasi dalam penelitian ini adalah seluruh \\
Dipublikasikan $: 2-12-2019$ & mahasiswa jurusan PPKn tahun pelajaran 2018/2019. Sampel penelitian \\
\hline Kata kunci: & ini adalah 28 mahasiswa. Metode yang digunakan dalam penelitian ini \\
Minat Belajar, & adalah metode penelitian deskriptif dengan pendekatan kuantitatif. \\
Prestasi Belajar & Penelitian deskriptif kuantitatif ini diharapkan mampu memberikan \\
Perkuliahan PKN & gambaran atau hasil tentang hubungan minat belajar dengan prestasi \\
& belajar mahasiswa semester 7 PPKn pada perkuliahan PKN.
\end{tabular}

Keywords:

Interest to learn,

Learning achievement

Civics learning

\begin{abstract}
This study aims to determine how the relationship of learning interest with the learning achievement of PPKn 7 semester students in PKN lectures. The population in this study were all students majoring in PPKn 2018/2019 academic year. The research sample was 28 students. The method used in this research is descriptive research method with a quantitative approach. This quantitative descriptive research is expected to be able to provide a picture or results about the relationship of learning interest with student learning achievement in the 7th semester of PPKn in Civic Education learning process.
\end{abstract}

Copyright ( 2019 Jaya Sasube Sore, Natanael F. Kaunang, Theodorus Pangalila. All Right Reserved

\section{Pendahuluan}

Pendidikan ialah salah satu hal yang pokok dalam kehidupan manusia. Melalui pendidikan akan dapat menciptakan manusia yang berpotensi cerdas, terampil, kreatif, berbudi pekerti luhur dan memiliki ide cemerlang sebagai bekal untuk memperoleh masa depan yang lebih baik lagi. Pada hakikatnya berfungsi untuk mengembangkan potensi yang dimiliki individu, membentuk kepribadian individu yang cakap, kreatif, mandiri, berkarakter, serta bertaqwa kepada Tuhan Yang Maha Esa. Hal ini selaras dengan Undang-Undang No. 20 Tahun 2003 Pasal 3 yang menyebutkan bahwa: "Pendidikan Nasional berfungsi mengembangkan kemampuan dan membentuk watak serta peradaban bangsa yang bermartabat dalam rangka mencerdaskan kehidupan bangsa, bertujuan untuk berkembangnya potensi siswa agar menjadi manusia yang beriman dan bertaqwa kepada Tuhan Yang Maha Esa, berakhlak mulia, sehat, berilmu, cakap, kreatif, mandiri, dan menjadi warga Negara yang demokratis serta bertanggung jawab".

"Dalam Undang-Undang Republik Indonesia No. 12 Tahun 2012 tentang Pendidikan Tinggi Pasal 4" dikatakan bahwa: "Pendidikan Tinggi berfungsi: (a). "mengembangkan kemampuan dan membentuk watak serta peradaban bangsa yang bermartabat dalam rangka mencerdaskan kehidupan bangsa"; (b). "mengembangkan Sivitas Akademika yang inovatif, responsif, kreatif, terampil, 
berdaya saing, dan kooperatif melalui pelaksanaan Tridharma"; dan (c). "mengembangkan Ilmu Pengetahuan dan Teknologi dengan memperhatikan dan menerapkan nilai Humaniora".

Mudiyahardjo, (2000:4) mengatakan bahwa "pendidikan adalah karya bersama yang berlangsung dalam suatu pola kehidupan insan tertentu". "Berdasarkan penjelasan pendidikan tersebut pendidikan nasional Indonesia merupakan system social dengan salah satu sector dalam keseluruhan kehidupan bangsa sedang membangun". "Pendidikan merupakan satu system bertugas membentuk manusia dengan kecakapan tertentu melalui proses belajar"

https://nie07independent.wordpress.com $/ \mathrm{k}$ onsep-pendidikan/ diakses tanggal 4 September 2019.

"Undang-Undang No. 14 Tahun 2005 tentang "Guru dan Dosen" dan Permendiknas No. 16 tahun 2007 tentang "Standar Kualifikasi Akademik dan Kompetensi Guru" menyebutkan bahwa seorang guru/dosen dituntut memiliki empat (4) kompetensi: yaitu, kompetensi pedagogik, kepribadian, sosial, dan professional".

"Berdasarkan Undang-Undang No. 14 Tahun 2005 tentang "Guru dan Dosen" di atas, Guru/Dosen di wajibkan menguasai empat kompetensi tersebut agar dapat menjadikan proses belajar menjadi lebih baik dan dapat dengan mudah meningkatkan minat belajar dan menghasilkan prestasi yg lebih baik". "Namun Salah satu kompetensi penting yang kadang dilupakan oleh dosen adalah kompetensi social". "Kompetensi sosial adalah kemampuan dosen untuk berkomunikasi dan berinteraksi secara efektif dan efisien dengan mahasiswa, sesama dosen, orang tua/wali peserta didik, dan masyarakat. Manusia merupakan makhluk sosial yang tidak dapathidup tanpa bantuan orang lain". "Oleh karena itu, dosen sebagai manusia perlu berinteraksi dengan manusia lainnya". "Interaksi sosial yang menjadi syarat utama terjadinya aktivitas-aktivitas sosial ini merupakan hubungan sosial yang dinamis". "Permasalahan yang ditemui di lapangan, secara khusus di Jurusan PPKn dalam proses perkuliahan masih ada mahasiswa yang mengeluhkan soal dosen yang tidak memiliki kemampuan untuk berinteraksi dengan mahasiswa sebagai peserta didik". (Pangalila, 2017)

Berdasarkan hasil penelitian dari (Pangalila, 2017) yang dilakukan pada "dosen dan mahasiswa di jurusan PPKn FIS Unima ditemukan bahwa hubungan interaksi dosen dan mahasiswa berjalan dengan baik". "Berdasarkan hasil wawancara dengan beberapa mahasiswa terungkap bahwa hubungan interaksi berjalan dengan baik". "Mahasiswa tidak mengalami kesulitan ketika hendak berkomunikasi dengan dosen, khususnya dalam proses perkuliahaan". "Namun demikian ada beberapa mahasiswa juga yang mengatakan ada sebagian dosen di jurusan PPKn yang sulit untuk berinteraksi dengan mahasiswa karena dosen yang bersangkutan memang jarang berada di kampus". "Dari permasalahan tersebut maka peneliti menyimpulkan bahwa hal tersebutd dapat menjadi salah satu faktor menurunya minat belajar, karena guru/dosen jarang berinteraksi dengan mahasiswa dalam proses pembelajaran (teacher Center) khususnya pada MK PKN". "Hal ini sejalan dengan data yang di dapat dari fakta yang terjadi di kelas A \& B Semester 7 PPKn diketahui bahwa prestasi belajar mata pelajara PKN masih rendah". "Hal ini diketahui dari Hasil Ujian Akir Semester mata pelajaran PKN". "Peneliti mengasumsi bahwa hal Ini disebabkan oleh kurangnya minat belajar pada MK: PKn". "Minat belajar yang ada pada Mahasiswa dapat dilihat dari beberapa ciri yang nampak, yaitu adanya perasaan senang terhadap belajar, adanya keinginan yang tinggi terhadap penguasaan dan keterlibatan dengan kegiatan belajar, ada perasaan tertarik yang tinggi terhadap belajar, ada kesadaran sebagai subjek pendidikan dan sadar akan kebutuhan terhadap belajar, dan mengetahui tujuan belajar". 
"Keberhasilan belajar ditentukan oleh beberapa faktor yang salah satunya adalah minat belajar". Purwanto, (2010:66) mengatakan bahwa "minat merupakan landasan penting bagi seseorang untuk melakukan suatu kegiatan dengan baik yaitu dorongan seseorang untuk berbuat". (Djamarah, 2008:191) "mengatakan minat adalah satu rasa lebih suka dan keterikatan pada suatu hal atau aktifitas tanpa ada yang menyuruh".

"Namun Pada proses pembelajaran PKN guru/dosen jarang menggunakan media". "Guru/dosen cenderung menggunakan buku teks sebagai satusatunya sumber belajar sehingga proses pembelajaran menjadi tidak menarik dan perhatian mahasiswa berkurang". "Beberapa gejala yang telah dipaparkan di atas, Kurangnya Mahasiswa terlibat dalam pembelajaran kemudian membuat Mahasiswa menaruh perhatian yang rendah pada mata pelajaran PKn". "Perhatian yang rendah membuat siswa tidak dapat fokus dalam menerima pesan dan isi materi pembelajaran, yang kemudian berpengaruh pada prestasi belajar siswa pada mata pelajaran PKn".

Berdasarkan penelitian terdahulu yang telah dilakukan oleh Pangalila, (2017), diketahui banyak "faktor yang mempengaruhi minat belajar Mahasiswa PPKn semester 7 pada perkuliahan PKN sehingga menyebebkan prestasi belajar yang kurang memuaskan". "Sehubungan dengan masalah tersebut maka peneliti tertarik untuk meneliti permasalah tersebut". Dengan merumuskan judul penelitian yaitu 'Hubungan Minat Belajar dengan Prestasi Belajar Mahasiswa PPKn Semester 7 Pada Perkuliahan PKN".

Berdasarkan latar belakang dan identifikasi masalah yang telah diuraikan di atas, maka masalah dalam penelitian ini dibatasi pada "minat belajar dan prestasi belajar PKn Mahasiswa Sem 7 PPKn T.P 2018/2019". Rumusan masalah masalah penelitian ini adalah: Apakah ada Hubungan antara "Minat Belajar dengan
Prestasi belajar pada Mahasiswa PPKn sem 7 Pada MK PKn".

\section{Metode}

Pendekatan yang digunakan dalam penelitian ini adalah pendekatan penelitian yang bersifat kuantitatif, karena hasil data dari angket yang diperlukan untuk mengungkap masalah dalam bentuk skor angka data kuantitatif yang selanjutnya diolah dan diuji dengan teknik analisis statistika.

Tempat penelitian ini adalah di kelas A dan B jurusan PPKn semester 7'. Adapun pemilihan lokasi tersebut dengan alasan sebagai berikut: Adanya relevansi masalah yang akan diteliti di kelas tersebut. Lokasi relatif dekat dengan domosili peneliti, sehingga mudah dijangkau dan bisa lebih efisien (waktu dan biaya).

Waktu penelitian ini dilaksanakan kurang lebih selama 1 bulan di Kelas A dan B jurusan PPKn semester 7 T.A 2015/2016.

Populasi adalah seluruh mahasiswa PPKn: obyek/subyek yang mempunyai kualitas dan karakteristik tertentu yang ditetapkan oleh peneliti untuk dipelajari dan kemudian ditarik kesimpulan. Jadi populasi bukan hanya orang tetapi juga obyek dan benda-benda alam yang lain. Populasi bukan sekedar jumlah yang ada pada obyek/subyek yang dipelajari,tetapi meliputi seluruh karakteristik/sifat yang dimiliki oleh subyek atau obyek itu (Sugiyono, 2011:20)

Berdasarkan pendapat di atas, maka dapat disimpulkan bahwa yang dimaksudkan populasi dalam penelitian ini adalah keseluruhan mahasiswa PPKn yang dijadikan sebagai sumber data dalam penelitian yaitu mahasiswa tahun angkatan 2014 s/d 2018 sebanyak 350 mahasiswa. Adapun populasi penelitian ini adalah seluruh mahasiswa Jurusan PPKn.

Sampel adalah bagian dari jumlah dan karakteristik yang dimiliki oleh populasi tersebut. Bila populasi besar, dan peneliti tidak mungkin mempelajari semua yang ada pada populasi, misalnya keterbatasan dana, tenaga dan waktu maka peneliti dapat 
mengunakan sampel yang diambil dari populasi itu. Sampel dalam penelitian ini akan diambil 1 kelas semester 7 PPKn yang berjumlah 28 mahasiswa. Arikunto (1998: 120) menjelaskan pengertian "sampel penelitian ini adalah sebagian atau wakil dari keseluruhan (jumlah) yang akan diteliti”. Berdasarkan pendapat di atas dapat disimpulkan bahwa sampel yang dimaksudkan dalam penelitian ini adalah sebagian dari jumlah keseluruhan mahasiswa yang dijadikan sebagai sumber data dalam penelitian.

Kelas Populasi Sampel mahasiswa semester 7 PPKn

Tabel. 1

\begin{tabular}{|c|c|c|c|c|}
\hline \multirow{2}{*}{ No } & Kelas & \multicolumn{2}{|c|}{$\begin{array}{c}\text { Jenis } \\
\text { Kelami } \\
\text { n }\end{array}$} & $\begin{array}{c}\text { Jumla } \\
\text { h }\end{array}$ \\
\cline { 3 - 4 } & & L & P & \\
\hline 1 & Kelas A & 6 & 7 & 13 \\
\hline 2 & Kelas B & 7 & 8 & 15 \\
\hline & Total & $\mathbf{1 3}$ & $\mathbf{1 5}$ & $\mathbf{2 8}$ \\
\hline
\end{tabular}

Beberapa teknik dalam pengumpulan data penelitian ini dilakukan sebagai berikut:

1) Teknik Angket.

"Teknik pengumpulan data penelitian ini adalah dengan teknik angket untuk data variabel tentang pelayanan guru/dosen dengan kedisiplin belajar Mahasiswa".

Langkah yang dilakukan dalam pengumpulan data melalui angket dalam penelitian ini adalah sebagai berikut:

a) "Mempersiapkan kisi-kisi dan indikator angket"

b) "Membuat pertanyaan sesuai dengan indikator angket yang telah ditentukan, dan selanjutnya dikonsultasikan pada Dosen Pembimbing"

c) "Melakukan try out angket dan menganalisis hasil try out"

d) "Menyebarkan angket pada siswa untuk penelitian"

e) "Melakukan analisis hasil penelitian"

2) Dokumentasi.

"Teknik studi dokumen, terutama untuk keperluan data tentang keadaan mahasiswa, guru/dosen dan berbagai dokumen yang relevan dengan keperluan pengumpulan data penelitian ini".

"Langkah yang dilakukan dalam pengumpulan data melalui teknik studi dokumentasi dalam penelitian ini adalah mengumpulkan data-data yang berhubungan dengan keadaan mahasiswa seperti data pribadi, dan data tentang kegiatan mahasiswa"

3) Teknik Observasi.

Teknik ini dilakukan untuk mengamati berbagai keadaan mahasiswa". "Langkah dalam pengumpulan data melalui teknik observasi adalah mengamati menggunakan lembar observasi tentang semua aktivitas mahasiswa selama pelaksanaan penelitian yaitu saat melakukan pembelajaran".

"Penelitian ini untuk mengungkap tentang hubungan Minat Belajar dengan Prestasi Belajar Mahasiswa PPKn Semester 7 pada perkuliahan PKn. Adapun teknik analisis data yaitu dengan Korelasi Product Moment.

$$
\begin{aligned}
& \text { "rXY =" } \\
& \text { "rXY = Koefisien Korelasi X dan } \\
& \mathrm{Y} " \\
& \text { "= Produk dari X dan Y" } \\
& \text { "= Kuadrat dari Variabel X" } \\
& \text { "= Kuadrat dari Variabel Y" } \\
& \text { "N = Jumlah Responden" }
\end{aligned}
$$

\section{Uji Korelasional}

Ukuran sampel dalam penelitian hanya berjumlah 24 responden, maka alat analisa data yang telah terjaring menggunakan analisa korelasi Spearmen dengan formula":

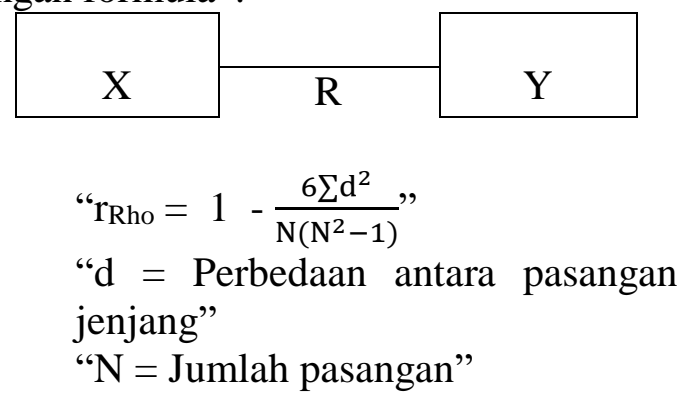

\section{Uji Signifikansi}

"Untuk menguji hipotesis penelitian, menggunakan uji $\mathbf{t}$ dengan formula sebagai berikut": 


$$
\text { "t }=\frac{\mathrm{r} \sqrt{\mathrm{N}-2}}{\sqrt{1-\mathrm{r}^{2}}},
$$

\section{Hasil dan Pembahasan \\ Uji Korelasional}

Dari hasil analisa korelasi, diperoleh nilai $r=0.753$ ini artinya bahwa hubungan antara variabel $\mathrm{X}$ dan $\mathrm{Y}$ bersifat positif; ini dapat juga bermakna bahwa variabel minat belajar berhubungan yang signifikan dengan variabelprestasi belajar".

\section{Uji Determinasi}

Untuk mengetahui kontribusi variabel minat belajar terhadap prestasi belajar maka dicari koefisien determinasi $\left(\mathrm{r}^{2}\right)$ yang merupakan kuadrat dan koefisien korelasi, yaitu:

$$
\begin{aligned}
& " r^{2}=(r)^{2} \times 100 \% " \\
& " r^{2}=(0,75)^{2} \times 100 \% " \\
& " r^{2}=0,567 \text { x 100\%" } \\
& " r^{2}=56 \% \text { (pembulatan)" }
\end{aligned}
$$

Koefisien determinasi tersebut mengandung arti secara statistik 56\% variabelminat belajardapat dijelaskan oleh variabel prestasi belajar. Artinya bahwa $56 \%$ variabel profesionalitas guru berhubungan dengan variable prestasi belajar. Sedangkan sisanya $44 \%$ dijelaskan oleh variabel lainnya di luar variabel minat belajaryang tidak di bahas dalam penelitian ini.

\section{Uji Signifikansi} rumus";

Untuk uji signifikansi digunakan

$$
t=\frac{r \sqrt{n-2}}{\sqrt{1-r^{2}}}
$$

Pengujian signifikansi (keberartian) korelasi ini akan dilakukan melalui hipotesis nol $-\mathrm{H}_{\mathrm{o}}-($ yakni $\mathrm{p}-0)$ dengan hipotesis tandingan $-\mathrm{H}_{1}-($ yakni $\mathrm{p}=0)$ melawan hipotesis tandingan $-\mathrm{H}_{1}-$ (yakni $\mathrm{p} \neq 0$ )". Pernyataan hipotesis nol ini adalah: "Korelasi antara X dan Y tidak berarti (tidak signifikan)". Sedangkan pernyataan hipotesis tandingan $\left(\mathrm{H}_{1}\right)$ adalah: "Korelasi antara $\mathrm{X}$ dan $\mathrm{Y}$ berarti (signifikan).

\section{Kriteria pengujiannya adalah :}

Tolak hipotesis nol $\left(\mathrm{H}_{0}\right) \mathrm{p}=0$ jika $\boldsymbol{t}_{\text {hitung }}$ lebih besar dari $\boldsymbol{t}_{\text {tabel, }}$, dan menerima hipotesis tandingan $\left(\mathrm{H}_{1}\right)$ ". "Dalam hal lainnya atau yang berbeda dengan itu maka hipotesis nol $\left(\mathrm{H}_{0}\right)$ diterima, dan hipotesis tandingan $\left(\mathrm{H}_{1}\right)$ ditolak".

\section{Pengujian :}

Diketahui :

"r $=0,75$ "

" $r{ }^{2}=0,56 "$

"n = 19"

Maka diperoleh :

$$
\begin{aligned}
& \text { t }=0,75 \sqrt{\frac{28-2}{1-0,56}} \\
& \text { " } t=0,75 \sqrt{\frac{26}{0,44}}, \\
& " t=0,75 \sqrt{59.0909 \ldots . "} \\
& " t=0,75 \times 7.6870 \ldots . . \\
& " t_{h}=5.765 \ldots ., \\
& \text { " } t_{h}=5.76 \text { (pembulatan)" }
\end{aligned}
$$

Pada taraf nyata 0,05 dan dk $\mathrm{n}-2=$ 26 daftar tabel $t$ diperoleh $t$ tabel sebesar 2.059 yang jauh lebih kecil dari $t_{\text {hitung }} 5.76$. Ini berarti hipotesis nol yakni $\mathrm{p}=0$ ditolak. Ini artinya bahwa hipotesis yang menyatakan bahwa korelasi antara variabel $\mathrm{X}$ dan $\mathrm{Y}$ tidak berarti (tidak signifikan) ditolak kebenarannya". "Dengan demikian dapat disimpulkan bahwa korelasi antara variabel $\mathrm{X}$ dan $\mathrm{Y}$ berarti (signifikan).

\section{Uji Hipotesis}

Pengujian Hipotesis dilakukan untuk mengetahui ada-tidaknya pengaruh antara variabel bebas dan teerikat. Pengujian hipotesis ini mengunakan taraf signifikansi 5\%". Harga yang diperoleh dari perhitungan Perhitungan statistik dikonsultasikan dengan nilai dalam table. Apabila harga $r_{\text {hitung }}$ lebih besar dari $t_{\text {tabel }}$ maka koefisien dikatakan signifikan dan begitu sebaliknya". "Dan berdasarkan hasil analisis data di yang telah dilakukan oleh peneliti diketahui harga $r_{\text {hitung }}$ lebih besar dari $t_{\text {tabel }}$ yaitu $t_{\text {tabel }}$ sebesar 2.074 yang jauh lebih kecil dari $t_{\text {hitung }} 5.76$ itu artinya terdapat hubungan yang positif dan signifikan antara minat belajar dengan 
prestasi belajar mahasiswa PPKn semester 7 pada perkuliahan $\mathrm{PKN}$.

Penelitian ini bertujuan untuk menguji adanya hubungan minat belajar dengan prestasi belajar pada mahasiswa PPKn semester 7 terhadap perkuliahan PKN.

Berdasarkan hasil penelitian menunjukkan bahwa ada hubungan yang signifikan antara minat belajar terhadap prestasi belajar mahasiswa semester tuju yang ditunjukkan dari uji signifikansi (Uji t) yang diperoleh $t_{\text {tabel }}$ sebesar 2.074 yang jauh lebih kecil dari $t_{\text {hitung }}$ 5.76. yang artinya terdapat hubungan yang positif yang sangat besar antara minat belajar terhadap prestasi belajar mahasiswa PPKn semester 7 tahun angkatan 2015/2016.

Dalam hasil analisis, dijelaskan bahwa terdapat hubungan yang positif dan signifikan antara minat belajar dengan prestasi belajar pada mahasiswa PPKn semester 7 terhadap perkuliahan PKN". Hal ini berkaitan dengan kajian teori yang menjelaskan bahwa menurut Slameto (Mun'Im, 2008:7) minat adalah suatu rasa lebih suka dan rasa keterikatan pada suatu hal atau aktifitas tanpa ada yang menyuruh. Selain itu juga minat termasuk dalam bagian dari faktor yang mempengaruhi suatu keberhasilan. Menurut W.S. Winkel, (2004) prestasi adalah bukti suatu usaha yang dapat di capai dalam waktu tertentu dan dapat di ukur dengan suatu alat/tes. Prestasi belajar erat kaitanya dengan penguasaan pengetahuan semakin tinggi prestasi belajar yang diperoleh mahasiswa, maka semakin tinggi pula pengetahuan diperoleh mahasiswa dalam mata kuliah tertentu. Secara umum hal ini dilihat melalui tes yang diberikan oleh dosen mata kuliah yang bersangkutan. Dan keberhasilan dalam hal ini adalah adanya minat pada diri mahasiswa untuk mau belajar agar mendapatkan prestasi yang lebih baik.

Dengan adanya minat belajar dalam proses belajar maka mahasiswa akan terdorong untuk mencapai sasaran dan tujuan karena yakin dan sadar akan kebaikan tentang kepentingan dan manfaatnya dari belajar. Minat belajar mahasiswa dapat menentukan baik tidaknya dalam mencapai tujuan sehingga semakin besar minat belajar Mahasiswa akan semakin besar kesuksesan belajarnya. "Minat belajar adalah merupakan salah satu faktor yang sangat penting dalam meraih nilai atau hasil yang maksimal dalam pembelajaran". "Selain itu minat belajar menjadikan diri bersemangat untuk mencari tahu apa yang belum pernah kita ketahuai sebelumnya".

\section{Simpulan}

Berdasarkan hasil penelitian menunjukkan bahwa ada hubungan yang signifikan antara minat belajar terhadap prestasi belajar mahasiswa semester tuju yang ditunjukkan dari uji signifikansi (Uji t) yang diperoleh ttabel sebesar 2.074 yang jauh lebih kecil dari thitung 5.76". "yang artinya terdapat hubungan yang positif yang sangat besar antara minat belajar terhadap prestasi belajar mahasiswa PPKn semester 7 tahun angkatan 2015/2016".

\section{Referensi}

Djamarah. (2008). Psikologi Belajar. Jakarta: Rineka Cipta.

Mudiyahardjo, R. (2000). Pengantar Pendidikan: Sebuah Study Awal Tentang Dasar-Dasar Pendidikan Pada Umumnya Dan Pendidikan Di Indonesia. Jakarta: Raja Grafindo Persada.

Pangalila, T. (2017). Interaksi Sosial Dosen dan Mahasiswa Dalam Proses Perkuliahan di Jurusan PPKn FIS Unima. PKn Progresif, 12(2). Retrieved from http://jurnal.fkip.uns.ac.id

Purwanto, N. (2010). Psikologi Pendidikan. Bandung: Remaja Rosdakarya.

Sugiyono. (2011). Metode Penelitian Kuantitatif Kualitatif $R \& D$. Bandung: ALFABETA.

W. S. Winkel. (2004). Psikologi Pengajaran. Jakarta: Grafindo. 